\title{
Effects of tourist boats on the behaviour of Indo-Pacific bottlenose dolphins off the south coast of Zanzibar
}

\author{
Fredrik Christiansen $^{1, *}$, David Lusseau ${ }^{2}$, Eva Stensland ${ }^{1}$, Per Berggren ${ }^{1,3}$ \\ ${ }^{1}$ Stockholm University, Department of Zoology, 10691 Stockholm, Sweden \\ ${ }^{2}$ University of Aberdeen, Institute of Biological and Environmental Sciences, Aberdeen AB24 2TZ, UK \\ ${ }^{3}$ Present address: School of Marine Science and Technology, University of Newcastle upon Tyne, Newcastle NE1 7RU, UK
}

\begin{abstract}
The short-term effects of tourist boats on the behaviour of Indo-Pacific bottlenose dolphins Tursiops aduncus were investigated off the south coast of Zanzibar, Tanzania, by comparing dolphin group behaviour in the presence (impact) and absence (control) of tourist boats. Groupfollows were conducted from a carefully maneuvered (non-invasive) independent research vessel and behavioural data on group activity were collected using scan sampling methods. By using a timediscrete Markov chain model, the transition probabilities of passing/changing from one behavioural state to another were calculated and compared between impact and control situations. The data were further used to construct behavioural budgets. In the presence of tourist boats, dolphins were less likely to stay in a resting or socialising activity but were more likely to start travelling or foraging, as inferred from the Markov chain model. The behavioral budgets showed that foraging, resting and socialising all decreased as an effect of tourist boat presence, while travelling increased. The behavioural responses are likely to have energetic implications, mainly by increasing physical demands. Further, the results demonstrate that the current level of tourism intensity off the south coast of Zanzibar affects the dolphins' cumulative behavioural budget. Regulations on dolphin tourism are therefore urgently needed to minimise potential long-term negative effects on the dolphins.
\end{abstract}

KEY WORDS: Dolphin tourism - Tourism impact • Behavioural response · Tursiops aduncus . Markov chains · Behavioural budget · East Africa

\section{INTRODUCTION}

Throughout the world, cetacean-watching is a rapidly growing industry (Hoyt 2001). It presents a potentially sustainable use of cetaceans and an economically viable alternative to whaling (Hoyt 1993). Cetacean-watching also improves people's attitude toward the marine environment (Orams 1997) and promotes public support for conservation issues that the targeted species face (Duffus \& Dearden 1993), while simultaneously benefiting local economies (Hoyt 2001, Berggren et al. 2007). However, during the last decade cetaceanwatching has become more close-up and interactive instead of the traditional passive viewing from a safe distance (Spradlin et al. 2001). This puts cetaceans at risk of being harassed and injured by an unknown number of unpredictable impacts associated with cetaceanwatching (Frohoff 2001, Bejder et al. 2006a). Previous studies have shown that dolphins react to disturbances by showing various behavioural changes including changes in activity, speed, movement, diving behaviour, group formation and vocalisation (Au \& Perryman 1982, Janik \& Thompson 1996, Constantine \& Baker 1997, Nowacek et al. 2001, Van Parijs \& Corkeron 2001, Lusseau 2003a, Bejder et al. 2006a, Stensland \& Berggren 2007). Some of these impacts may be longterm and life-threatening, both at the individual and population level (Bejder et al. 2006a).

A small resident population of $136(95 \%$ CIs $=124$, 172) Indo-Pacific bottlenose dolphins Tursiops aduncus has been studied since 1998 off the south coast of Zanzibar, Tanzania (Stensland et al. 2006). Analyses of 
genetic differentiation in mtDNA sequence data have shown significant separation between dolphins found in this area and Indo-Pacific bottlenose dolphins off northern Zanzibar, despite the relatively short distance (approx. $80 \mathrm{~km}$ ) between these areas (Särnblad et al. unpubl.). Studies investigating fisheries bycatch of Indo-Pacific bottlenose dolphins in artisanal drift-set and bottom-set gillnet fisheries off the south coast of Zanzibar have shown that $>9 \%$ of the estimated population size is killed per year as bycatch, which is not considered sustainable (Berggren et al. 2007). These investigations show that the Indo-Pacific bottlenose dolphins found off the South coast of Zanzibar are threatened by anthropogenic activities and should be treated as a separate management unit when assessing the impact from bycatch, dolphin tourism and other anthropogenic threats. During the past few decades, the dolphins in this area have been hunted directly for their meat, oil and blubber, as well as being killed indirectly as bycatch in fisheries (Amir et al. 2002). In 1992, dolphin-watching tourism was started off the south coast of Zanzibar by villagers from Kizimkazi, gradually replacing the previous dolphin hunt in the area (Amir \& Jiddawi 2001). The industry has become a major contributor to the local economies and to Zanzibar in general, where the economic opportunities are otherwise very limited (Berggren et al. 2007). Today, Zanzibar is one of the few areas in the world where a cetacean hunt has been directly replaced by cetacean tourism as a socio-economic alternative (Berggren et al. 2007). Still, for dolphin-watching tourism to persist as a long-term ecologically and economically viable industry, it is important that dolphin-watching tourism is conducted in a non-invasive way so as to not have long-term negative effects on the population.

The purpose of the boat-based dolphin-watch and swim tours conducted off the south coast of Zanzibar is for people to interact with the dolphins. A total of 44 boats are used to conduct dolphin tourism, operating from the 2 villages of Kizimkazi-Dimbani and Kizimkazi-Mkungoni (F. Christiansen pers. obs. January 2007). The local wooden boats used are 5 to $6 \mathrm{~m}$ long with $15 \mathrm{hp} \mathrm{2-stroke} \mathrm{outboard} \mathrm{engines} \mathrm{and} \mathrm{the} \mathrm{capacity}$ to carry up to 20 tourists on a single trip. When a group of dolphins is sighted during a dolphin-watching trip, the boat approaches the group until it is right next to the dolphins. The tourists onboard then jump or calmly enter the water to observe and swim with the dolphins. During an encounter, a single dolphin group can be subjected to multiple tourist boats for several hours. Previous tourism impact studies in the area focused on the effects on dolphins caused by the violation of recommended dolphin tourism guidelines (Englund 2001, Jedensjö 2005). Another study concentrated on the impact of tourism on nursing female dolphins (Stens- land \& Berggren 2007). The results of these studies have shown that dolphin behaviours were affected negatively by increased levels of tourism activities and by violation of the guidelines. Stensland and Berggren (2007) found that the proportion of erratic (non-directional) movement of dolphins increased significantly when more than 2 tourist boats were interacting with a group of dolphins. The proportion of active dives also increased as a result of tourist boats being present and female dolphins were shown to travel more frequently in the presence of tourist boats (Stensland \& Berggren 2007). Further, Stensland \& Berggren (2007) speculated that these short-term behavioural changes might lead to changes in habitat use by nursing females and/or lead to long-term negative effects on the dolphin population by reducing individual fitness. It is likely that dolphins are interacting with tourist boats multiple times per day, all year round. Since the dolphin population in the area is small, resident and potentially isolated (Stensland et al. 2006, A. Särnblad et al. unpubl.), daily disturbance from tourist boats can be likened to habitat degradation (Corkeron 2004), causing cumulative negative effects both at individual and population levels (Duffus \& Dearden 1990, Bejder et al. 2006a).

The reaction of a dolphin to a potential source of disturbance, such as a tourist boat, depends on the current behaviour of the animal (Au \& Perryman 1982, Constantine \& Baker 1997). In this study, we take this factor into consideration by using Markov chain analyses to calculate the probability that a dolphin group will change from one behavioural state (subcategories of behaviours defined along the behavioural range of an animal) to another when tourist boats are either present or absent (Lusseau 2003a). The study further investigates whether these effects alter the dolphins' behavioural budgets: i.e. the proportion of time the dolphins spend in each behavioural state. Since the behavioural budget is directly related to the energy budget of the dolphin population, changes in the former can be calculated to give information on the biological significance of an impact (Lusseau 2003a).

\section{MATERIALS AND METHODS}

Data collection. The activity of Indo-Pacific bottlenose dolphins and tourist boats was recorded between January 2007 and April 2007 off the south coast of Zanzibar, Tanzania (Unguja Island: $6^{\circ} 26^{\prime} \mathrm{S}$, $39^{\circ} 28^{\prime} \mathrm{E}$ ). The study area was defined as a $26 \mathrm{~km}^{2}$ area around the southern tip of Zanzibar (Fig. 1), based on the results of previous studies of Indo-Pacific bottlenose dolphins in the area (Stensland et al. 2006). Stensland et al. (2006) found that the density of Indo- 


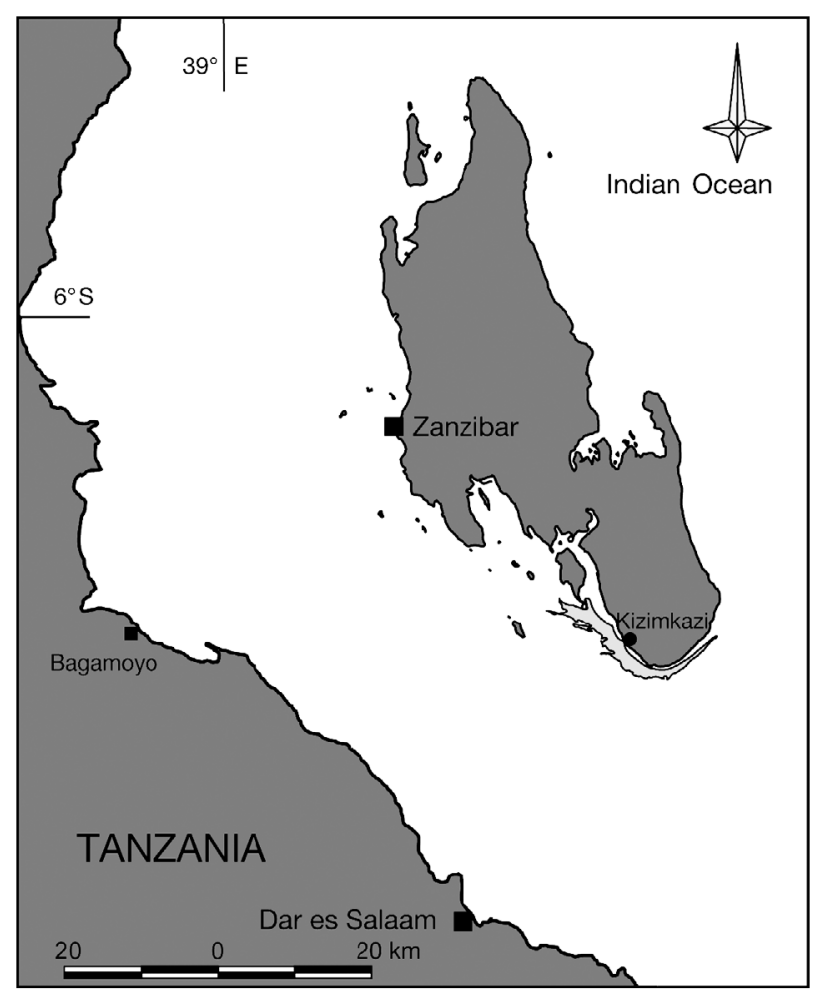

Fig. 1. Map of Zanzibar, Tanzania. The light grey area represents the $26 \mathrm{~km}^{2}$ study area off the south coast

Pacific bottlenose dolphins at this site was highly concentrated within only $8 \%\left(1.7 \mathrm{~km}^{2}\right)$ of the entire study area. Dolphin tourism activities were concentrated within a $1.9 \mathrm{~km}^{2}$ area, which overlapped with the area used by the Indo-Pacific bottlenose dolphin by $44 \%$ (Stensland et al. 2006). It was therefore appropriate to use the same study area for this study, as it includes the high intensity areas used by both the dolphins and dolphin tourism.

Data were collected from an independent research vessel, a $5 \mathrm{~m}$ boat powered by an $80 \mathrm{hp} 2$-stroke outboard engine. Even though the engine used by the research vessel was more powerful than those used by tourist boats ( $80 \mathrm{hp}$ compared to $15 \mathrm{hp}$, respectively), this does not mean that the acoustic disturbance from the research vessel was higher than from the tourist boats. It has been shown that the operating speed of the engine, the distance from the animals, as well as the frequency of gear shift are much more important in terms of acoustic disturbance to cetaceans than the engine itself (Jensen et al. 2009). To minimise the impact on the dolphins, the research vessel was always maneuvered in a careful way by avoiding rapid changes in speed and course, and thereby also avoiding shifts of gears. The speed of the research vessel was always kept as low as possible to match the speed of the dolphin groups and to avoid noise caused by cavitation.
The dolphin groups were always approached from the side and rear and the vessel was kept parallel to the groups at a distance of $20 \mathrm{~m}$ or more, both in the presence and absence of tourist boats (Nowacek et al. 2001, Lusseau 2003b). In contrast, tourist boats normally approach the dolphins at high speeds and at very close range $(<5 \mathrm{~m})$, and make frequent gear changes (e.g. when reversing to pick up swimmers). Still, the careful maneuvering of the research vessel does not exclude a possible effect from the vessel, but the measured effects from the tourist boats occur over and above this effect (Constantine et al. 2003).

Groups of Indo-Pacific bottlenose dolphins were sampled to investigate the effect of boat interactions at the group level. A group was defined as a collection of 2 or more adult dolphins in which no individual was further than $10 \mathrm{~m}$ from the nearest dolphin (ten meter chain rule, as in Smolker et al. 1992). Only the behaviour of non-calves was considered since the behaviour of calves was not considered independent of that of their mothers.

The behaviour and associated data of the dolphin groups were sampled every $15 \mathrm{~min}$. At the beginning of each sample, the predominant behavioural state of the dolphin group was determined and recorded by focal-group scan sampling (Altmann 1974). The different behavioural states for dolphin activity are defined in Table 1 (after Mann \& Smuts 1999, Stensland et al. 2006). The group-follows ended when weather conditions prevented data collection or when the dolphin group was lost. Interactions between tourist boats and a dolphin group were defined as beginning when 1 or more vessels were within $50 \mathrm{~m}$ of the dolphin group (Stensland \& Berggren 2007); the interaction ended

Table 1. Tursiops aduncus. Definitions of behavioural states

\begin{tabular}{|ll}
\hline Behavioural state & Definition \\
\hline Foraging (FOR) & $\begin{array}{l}\text { Rapid energetic surfacings, frequent } \\
\text { directional changes, fish chases and } \\
\text { dolphins making deeper (peduncle } \\
\text { and tail-out dives) and longer dives }\end{array}$ \\
Resting (RES) & $\begin{array}{l}\text { Low activity level, dolphins moving } \\
\text { slowly (speed <2 knots); slow sur- } \\
\text { facings, 3-4 times before diving for } \\
\text { an extended period of time }\end{array}$ \\
Socialising (SOC) & $\begin{array}{l}\text { Petting, rubbing, mounting, chasing, } \\
\text { genital inspections, play, displays, } \\
\text { and other physical contact between } \\
\text { individuals }\end{array}$ \\
Travelling (TRA) & $\begin{array}{l}\text { Persistent and directional movement } \\
\text { (speed }>2 \text { knots); dolphins could be } \\
\text { meandering but still moving in a } \\
\text { general direction }\end{array}$ \\
\end{tabular}


when the last tourist boat leaving the group exceeded this distance. Due to sample size limitations, it was not possible to test the effect of different levels (numbers) of tourist boats on dolphin behaviour.

Data analysis. Behavioural transitions: Markov chains quantify the dependence of a succeeding event on preceding events (Guttorp 1995, Caswell 2001, Lusseau 2003a). Since this dependence can be affected by any extrinsic factor taking place between events, it is possible to calculate the probability that a dolphin group will change from one behavioural state to another when tourist boats are either present (impact) or absent (control). This effect can then be quantified and tested for by comparing these 2 probabilities (Lusseau 2003a).

Since scan sampling events were separated in time by 15 min intervals, first-order time-discrete Markov chains were used to investigate both the initial behavioural state of the dolphin group and the way this state changed by the time of the following scan sample event 15 min later (see Lusseau 2003a for details of analysis). In first-order Markov chains the succeeding event is only dependent on the immediately preceding event. This made it possible to arrange the data obtained from the scan sampling into 2-way contingency tables of preceding behavioural state versus succeeding behavioural state (Lusseau 2003a). Two contingency tables were constructed, 1 for control (no tourist boats present) and 1 for impact (tourist boats present) situations, depending on the presence of tourist boats interacting with the dolphin group between 2 behavioural samples. Following a tourist boat interaction, the first transition (the sample immediately succeeding the interaction) was discarded from the data set, since this could not be considered as either control or impact (Lusseau 2003a). To test the effect of tourist boat presence, the impact and control contingency tables were compared by using a goodness-of-fit test in SPSS 15.0 (SPSS).

Transition probabilities from preceding to succeeding behavioural state were calculated following Lusseau (2003a) for both control and impact contingency tables as:

$$
p_{i j}=\frac{a_{i j}}{\sum_{j=1}^{n} a_{i j}}, \sum_{j=1}^{n} p_{i j}=1
$$

where $i$ is the preceding behavioural state, $j$ is the succeeding behavioural state, $n$ is the total number of behavioural states (in this case 4 ), $a_{i j}$ is the number of transitions observed from behavioural state $i$ to $j$, and $p_{i j}$ is the transition probability from $i$ to $j$ in the Markov chain.

Since each transition is the proportion of time a succeeding behavioural state was observed following a preceding behavioural state, it is possible to test the effect of boat interactions on the transition probability matrices for dolphin activity by comparing each control transition to its corresponding impact transition using a 2-tailed Z-test for proportions (Fleiss 1981).

Behavioural budgets: Certain properties of the Markov chains make it possible to derive the behavioural budget of the dolphin population (i.e. the proportion of time the dolphins spend in each behavioural state) by Eigen analysis of the contingency tables (see Lusseau 2003a for details of analysis). Eigen analysis of both the control and impact matrices was performed using the Excel add-in PopTools (Version 2.3, CSIRO: www.cse.csiro.au/poptools/) to infer the respective behavioural budgets for both treatments. Differences between control and impact behavioural budgets were tested using a goodness-of-fit test and a 2-tailed $Z$-test for proportions (Fleiss 1981). For the Z-test, each behavioural state in the control behavioural budget was compared to its corresponding behavioural state in the impact behavioural budget. Finally, 95\% confidence intervals were calculated for the estimated proportion of time spent in each state.

Cumulative behavioural budgets: By adding the proportion of daytime hours (where the number of daytime hours is 12) that dolphin groups spent with tourist boats to the dolphins' behavioural budget, the cumulative behavioural budget of the dolphin population can be calculated (Lusseau 2003a). By comparing this budget to the control behavioural budget (undisturbed behaviour), the effect of tourist boats on the dolphins' daytime behavioural budget can be investigated. Following Lusseau (2003a), the cumulative behavioural budget was calculated as:

$$
\begin{aligned}
& \text { Cumulative budget }= \\
& (a \times \text { impact budget })+(b \times \text { control budget })
\end{aligned}
$$

where $a$ is the proportion of daytime hours (ranging from 0 to 1 ) that dolphins spend with tourist boats (thus following a behavioural budget similar to the impact chain), and $b$ is the remaining proportion of time per day $(1-a)$ that dolphins spend without tourist boats (thus following a behavioural budget similar to the control chain: Lusseau 2003a). By artificially varying the proportion of time per day that the dolphins spend with tourist boats from 0 to $100 \%$, it is possible to see at what level of tourism intensity the cumulative behavioural budget could become significantly affected, given the observed effect size and assuming that such effect size does not vary with daytime exposure rate (Lusseau 2004). The difference between the cumulative behavioural budgets and the control budget were tested with a goodness-of-fit test and a 2tailed Z-test for proportions (Fleiss 1981) for each behavioural state. 


\section{RESULTS}

During the study period, a total of $41 \mathrm{~d}$ were spent at sea following groups of Indo-Pacific bottlenose dolphins; $149 \mathrm{~h}$ of behavioural data were collected from 45 dolphin groups. This corresponds to 551 behavioural transitions, of which $346(63 \%)$ were recorded during impact and 205 (37\%) during control situations. There were no statistical differences in the size (1-way ANOVA-test, $F=1.443, \operatorname{df}$ (among) $=1$, $\mathrm{df}($ within $)=549, \mathrm{p}=0.230)$ and composition (relative proportion of adults, calves and young-of-the-year: Goodness-of-fit test, $\chi^{2}=0.003, \mathrm{df}=2, \mathrm{p}=0.998$ ) of the dolphin groups sampled during control and impact situations. The number of boats interacting simultaneously with a single group of dolphins varied between 1 and 13, with an average of 4 boats at a time $($ mean $=3.977 \pm 0.151 \mathrm{SE})$.

\section{Behavioural transitions}

The results from the Markov chain analysis show that the interactions with tourist boats had an effect on the transitions in behavioural states for dolphin activity (Goodness-of-fit test, $\chi^{2}=117.800, \mathrm{df}=9, \mathrm{p}<0.001$ ). This effect was not evenly distributed among the transitions. Overall, 5 behavioural transitions showed statistically significant differences $(\alpha=0.05)$ between impact and control situations (Fig. 2). Of these, 2 transitions, Resting $\rightarrow$ Resting $(Z$-test, $Z=3.782, \mathrm{p}<0.001)$ and Socialising $\rightarrow$ Socialising ( $Z$-test, $Z=3.182, \mathrm{p}<$ $0.002)$ decreased, while the other 3 transitions, Resting $\rightarrow$ Travelling $(Z$-test, $Z=-3.018, \mathrm{p}<0.003)$, Socialising $\rightarrow$ Foraging $(Z$-test, $Z=-2.641, \mathrm{p}<0.009)$, and Travelling $\rightarrow$ Travelling ( $Z$-test, $Z=-3.035, \mathrm{p}<0.003$ ), increased as an effect of tourist boats being present.

The magnitude of difference in transition probability was not homogenous for all transitions. Dolphins were less likely to stay in a Resting (Resting $\rightarrow$ Resting: 77 to $37 \%$ ) or Socialising (Socialising $\rightarrow$ Socialising: 71 to $30 \%$ ) state in the presence of tourist boats. Conversely, dolphins were 4 times more likely to start travelling from being at a resting state (Resting $\rightarrow$ Travelling) $(11-37 \%)$ and almost 10 times more likely to start foraging while being at a socialising state (Socialising $\rightarrow-$ Foraging: 3-26\%) in the presence of tourist boats. Finally, the likelihood of the dolphins staying in a travelling state (Travelling $\rightarrow$ Travelling) increased by approximately a third in the presence of tourist boats (63 to $81 \%$ ).

\section{Behavioural budgets}

All 4 behavioural states in the dolphins' behavioural budget were significantly affected by the tourist boats (Goodness-of-fit test, $\chi^{2}=107.702, \mathrm{df}=3, \mathrm{p}<0.001$ ).

Preceding activity

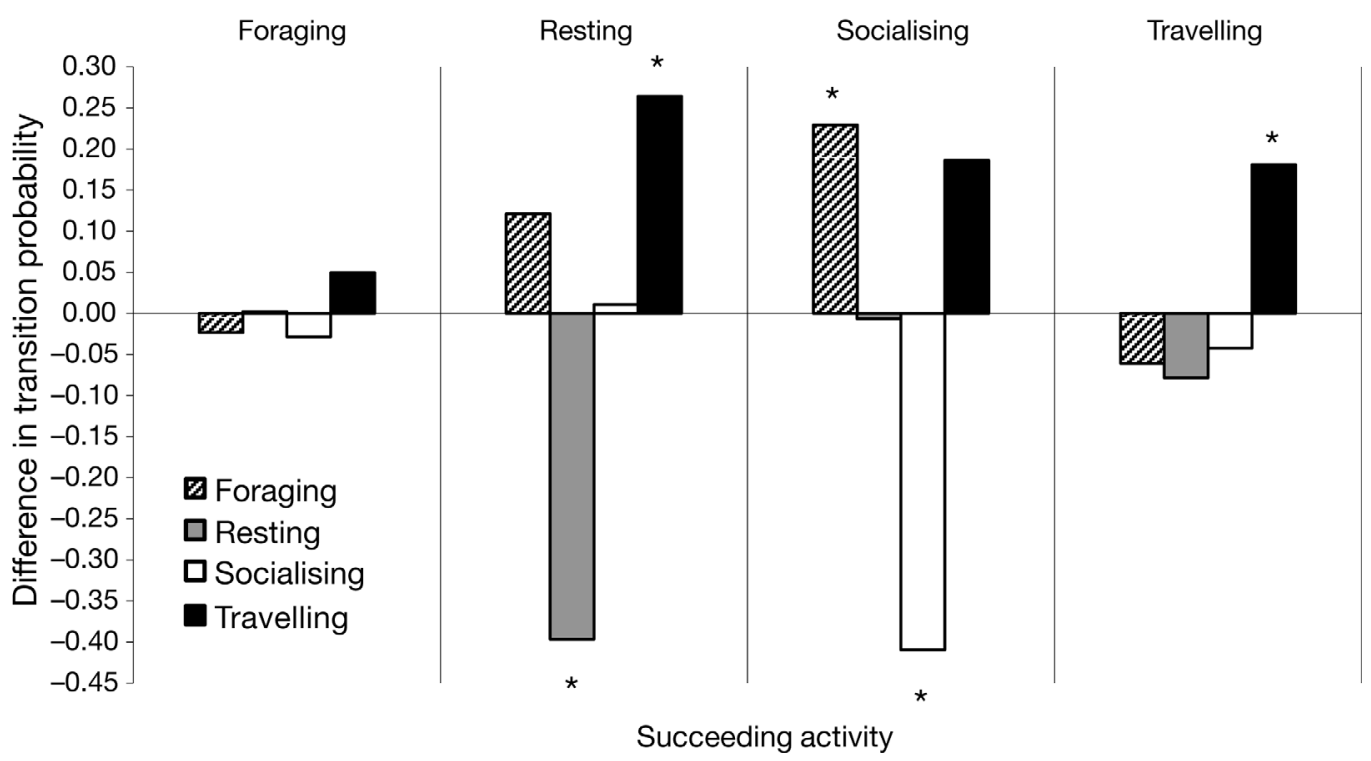

Fig. 2. Tursiops aduncus. Differences in transition probabilities between impact (tourist boats present) and control (no tourist

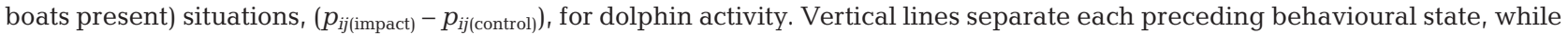
the bars represent the succeeding behavioural states (see legend). $\left(^{*}\right)$ indicate transitions with a significant difference $(\mathrm{p}<0.05)$ 
The dolphins spent a smaller proportion of their time foraging ( $Z$-test, $Z=3.453$, $\mathrm{p}<0.001$ ), resting (Z-test, $Z=7.733$, $\mathrm{p}<0.001)$ and socialising ( $Z$-test, $Z=$ 3.029, p < 0.003), and instead spent more time travelling ( $Z$-test, $Z=-10.228$, p < 0.001 ) as an effect of tourist boats being present (Fig. 3). Resting, being the dominant activity state during control situations, was the activity most affected by the tourist boats, decreased from 38\% during control to $10 \%$ during interactions with tourist boats. Foraging and socialising decreased to about half their control proportions, from 19 to $9 \%$ and from 10 to $4 \%$, respectively. Travelling more than doubled in proportion, from 33 to $77 \%$, becoming by far the most dominant activity state during interactions with tourist boats.

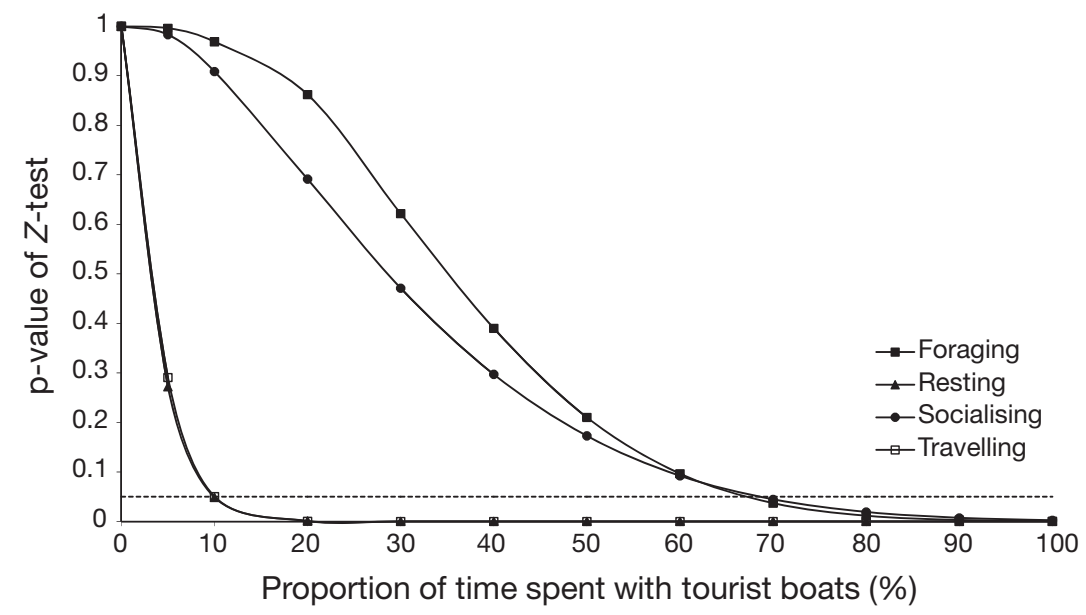

Fig. 4. Tursiops aduncus. The p-value of the difference between the cumulative behavioural budget and the control behavioural budget for dolphin activity. The proportion of time spent per day (daytime hours) with tourist boats was artificially varied from 0 to $100 \%$. Each curve corresponds to different behavioural states (see legend). Note that the curves representing resting and travelling are almost identical and overlap each other. Dotted line represents the statistical level of significance $(p<0.05)$

\section{Cumulative behavioural budgets}

The effects of different levels of tourism intensities on the dolphins' cumulative behavioural budget can be seen in Fig. 4. If effects build linearly, the cumulative resting and travelling behaviours of the dolphins are significantly affected at a tourism intensity of $10 \%$ of daytime hours, while it will take a tourism intensity of up to $70 \%$ before the cumulative foraging and socialising behaviours are significantly affected (Fig. 4). This shows that a tourism intensity of $10 \%$ per day is already sufficiently large to affect the cumulative behavioural budget for the dolphins off the south coast of Zanzibar.

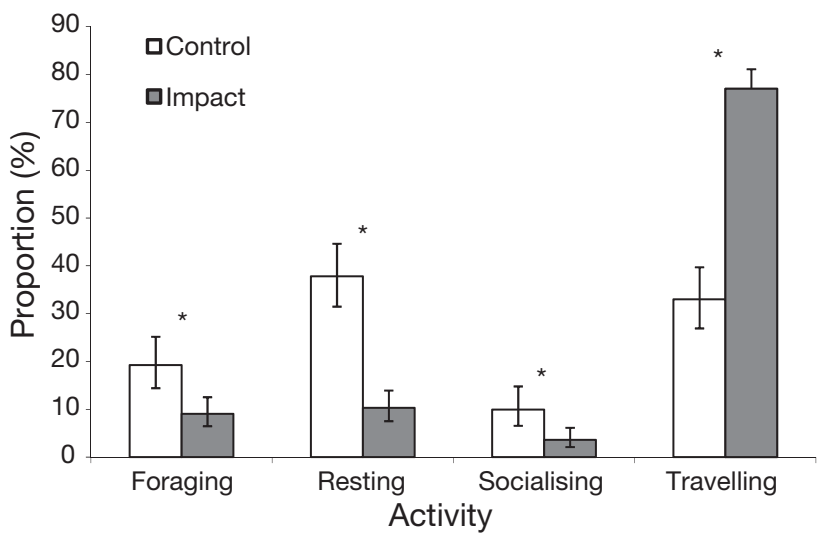

Fig. 3. Tursiops aduncus. Behavioural budget for dolphin activity: the proportion of time spent in each behavioural state during control (no tourist boats present) and impact (tourist boats present) situations. Error bars represent $95 \%$ confidence intervals. $\left(^{*}\right)$ indicates significant differences $(p<0.05)$

\section{DISCUSSION}

This study shows that the behaviour of Indo-Pacific bottlenose dolphins off the south coast of Zanzibar was significantly affected by interactions with tourist boats. The Markov chain transition analyses showed that the behavioural states changed significantly during tourist boat interactions, with dolphins being more likely to start travelling after a tourist boat interaction instead of staying in a resting or socialising state. The changes in behavioural states were sufficiently large to cause significant alterations to the dolphins' behavioural budget. The dolphins spent a smaller proportion of their time foraging, resting and socialising as an effect of tourist boats being present, and instead spent more time travelling.

A decrease in the time spent foraging is likely to result in a reduction in energy acquisition due to a decrease in food intake (Williams et al. 2006). Therefore, repeated interruptions by tourist boats during foraging are likely to have long-term negative effects on dolphin survival. Resting is important for the health of many animal species (Bishop 1999). A reduction in time spent resting due to human disturbance has been shown to induce physiological stress, cause an increase in heart rate and energetic costs, and reduce energy reserves for a variety of mammal and bird species (for review see Constantine et al. 2004). It is also possible that a reduction in energy reserves, resulting from a decrease in time spent resting, could increase the risk of predation due to a reduced alertness level in the dolphins. Since female dolphins mainly nurse their calves while resting (Stensland \& Berggren 2007), a 
reduction in the time spent resting could also reduce the time available for nursing, which could result in lower offspring survival (Stensland \& Berggren 2007). A reduction in the proportion of time spent resting due to interactions with tourist boats may therefore lead to a long-term decrease in survival and reproductive success, both for individuals and the population (Lusseau et al. 2006). If the sexual behaviours of dolphins, which are included in socialising, are interrupted by tourist boats, this could lead to a lower rate of successful mating attempts; this would in turn result in lower pregnancy rates and hence fewer offspring, which could have a long-term negative effect on the reproductive success of the population (Lusseau et al. 2006). Since travelling is a relatively energy consuming activity, it may lead to increased energetic demands for dolphins that are forced to increase the proportion of time they spend travelling to avoid tourist boats (Bejder et al. 1999). This could ultimately result in a reduced fitness on both individual and population level (Lusseau et al. 2006).

Dolphins off the south coast of Zanzibar are believed to be interacting with tourist boats for $\sim 43 \%$ of the daytime (Stensland \& Berggren 2007). This level of tourism intensity is high enough to affect the dolphins' cumulative resting and travelling behaviours, meaning that the daytime behavioural budget of the dolphins is significantly affected by the tourist boat interactions (Fig. 4).

The goal of an impact study is to link the short-term (immediate) effects, in this case effects of tourist boats on the behaviour of dolphins, to biologically significant long-term (lasting) effects on survival, reproduction and population size (Bejder \& Samuels 2003). In Shark Bay, Australia, tourist boats were found to be the main cause of a long-term decline in relative dolphin abundance (Bejder et al. 2006a). Only 2 tourist boats are active in Shark Bay and the tourism activities are strictly regulated by not allowing swimmers in the water and by having a set time limit of $15 \mathrm{~min}$ for each interaction (Bejder et al. 2006a). These results are alarming for Zanzibar, where no restrictions regarding swimming and number of boats allowed per dolphins group exist and where the majority of boat operators violate the issued guidelines. With a Zanzibar population size of $136(95 \%$ CIs $=124,172$ : Stensland et al. 2006), much smaller than the 800 of Shark Bay (Bejder et al. 2006b), the effects of tourist boats and swimmers in Zanzibar will most likely result in a long-term effect similar or worse than that in Shark Bay. Indeed, such effects on population viability have been observed in the small bottlenose dolphin population residing in Doubtful Sound, New Zealand (Lusseau et al. 2006) where the recent population decline, driven by a drastic reduction in reproductive success, is thought to be primarily caused by tourism interactions (Lusseau 2003b, 2004, Lusseau et al. 2006).

Alternatively, if the tourism intensity is too high, the only way for dolphins to deal with the increased energetic costs might be to switch to a long-term area avoidance strategy (Lusseau 2003a). Area avoidance means that dolphins either temporarily move away from a used area during periods when tourism intensity is high (Wells 1993, Allen \& Read 2000, Bejder et al. 2006b), or leave an area entirely to move to another area where they may remain (Forest 1999, Lusseau 2003a, Bejder et al. 2006b). For the Indo-Pacific bottlenose dolphins off the south coast of Zanzibar, an area avoidance strategy would most likely result in the animals having to spend a higher proportion of their time further offshore in deeper and less sheltered waters where they are out of reach of tourist boats. Large shark species are commonly found in these deeper offshore waters off Zanzibar (F. Christiansen pers. obs. January 2007), which indicate that an area avoidance strategy could lead to an increase in predation risk for the Indo-Pacific bottlenose dolphins.

Stensland et al. (2006) found that within-year and between-year recapture rates of the identified IndoPacific bottlenose dolphins in the study area $\left(26 \mathrm{~km}^{2}\right)$ indicate a resident population. Furthermore, the high intensity area of dolphin tourism overlaps with the area used by the Indo-Pacific bottlenose dolphin population by $44 \%$ (Stensland et al. 2006). However, the relatively small size of the study area needs to be taken into consideration; it is possible that the home range of some dolphins extends beyond the study area, meaning that the spatial extent of the tourist disturbance could possibly be less than what is indicated here.

\section{CONCLUSIONS}

The results of this study verify and give further strength to the conclusions made by previous impact studies off the south coast of Zanzibar: dolphin tourism activities in its current form have negative effects on the behaviour of the Indo-Pacific bottlenose dolphins in the area. This study has advanced the understanding of how tourism affects the Indo-Pacific bottlenose dolphins in the area by being the first group study to show the magnitude of the impact in relation to the behaviour of undisturbed dolphins. The study has further shown that tourism affects the behaviour of dolphins to such an extent that it compromises their cumulative behavioural budget. Behavioural changes, such as those found in this study, most likely cause increased energetic costs, which could have negative effects on the survival and reproduction of individual dolphins (Bejder \& Samuels 2003); this could ultimately 
cause a decline in population size and/or a change in habitat use (Anthony \& Blumstein 2000, Lusseau 2005, Lusseau et al. 2006).

The relatively small population size of the IndoPacific bottlenose dolphins (Stensland et al. 2006) and the possible genetic isolation of these animals off the South coast of Zanzibar (A. Särnblad et al. unpubl.) may further worsen the situation. More recent population size estimates and further research into the distribution range of this population of Indo-Pacific bottlenose dolphins is therefore urgently needed to be able to better understand its current status.

Dolphin-watching tourism is of great importance to the local communities and residents in Kizimkazi (Berggren et al. 2007). A reduction of the bycatch and regulation of dolphin-watching tourism is urgently needed to prevent a long-term decrease in survival and reproductive success that could result in a decline in population size and/or dolphins leaving the area. This would then result in a reduction in the tourism potential which would have serious socio-economic implications in the area.

To reduce the pressure from dolphin-watching tourism on the dolphins off the south coast of Zanzibar, a management option might be to have fewer tourists paying more money for the experience, a strategy supported by the result of a socio-economic study conducted in the area (Berggren et al. 2007). That would potentially lower the number of dolphin-watching trips off the south coast of Zanzibar, and thus the pressure on the dolphins, without reducing the economic benefits to the region. To minimise the effect of tourist boats and swimmers on dolphins during interactions, we recommend that the already available and issued guidelines for best dolphin tourism practice, issued by the Department of Fisheries and Marine Products in Zanzibar in 2003, are implemented.

Acknowledgements. We thank the Swedish International Development Agency (SIDA) and the Department of Zoology, Stockholm University, for their financial support. We thank O. Amir, Dr. A. Dubi, Dr. N. Jiddawi and J. Kifana at the Institute of Marine Sciences, University of Dar es Salaam, for their cooperation and logistic support during the field work. We also thank the Menai Bay office for approving the research in the Menai Bay Marine Conservation Area and the villagers of Kizimkazi for their hospitality and support. We thank M. Hällbom and K. J. Ramadhan for their assistance in the field. We also thank G. Bearzi and 2 anonymous reviewers for their comments and corrections, which helped to improve the manuscript greatly. Finally we thank J. P. Salier for his help and constructive comments on the text.

\section{LITERATURE CITED}

Allen MC, Read AJ (2000) Habitat selection of foraging bottlenose dolphins in relation to boat density near Clearwater, Florida. Mar Mamm Sci 16:815-824
Altmann J (1974) Observational study of behaviour: sampling methods. Behaviour 49:227-267

Amir OA, Jiddawi NS (2001) Dolphin tourism and community participation in Kizimkazi village, Zanzibar. In: Richmond MD, Francis J (eds) Marine science development in Tanzania and Eastern Africa. Proceedings of the 20th Anniversary Conference on Advances in Marine Science in Tanzania. Institute of Marine Sciences, University of Dar es Salaam/Western Indian Ocean Marine Science Association, Zanzibar, p 551-560

Amir OA, Berggren P, Jiddawi NS (2002) The incidental catch of dolphins in gillnet fisheries in Zanzibar, Tanzania. West. Indian Ocean J Mar Sci 1:155-162

> Anthony LL, Blumstein DT (2000) Integrating behaviour into wildlife conservation: the multiple ways that behaviour can reduce N-e. Biol Conserv 95:303-315

$\mathrm{Au}$ D, Perryman W (1982) Movement and speed of dolphin schools responding to an approaching ship. Fish Bull (US) 80:371-379

Bejder L, Samuels A (2003) Evaluating the effects of naturebased tourism on cetaceans. In: Gales N, Hindell M, Kirkwood R (eds) Marine mammals and humans: towards a sustainable balance: 480. CSIRO Publishing, Collingwood

Bejder L, Dawson SM, Harraway JA (1999) Responses by Hector's dolphins to boats and swimmers in Porpoise Bay, New Zealand. Mar Mamm Sci 15:738-750

Bejder L, Samuels A, Whitehead H, Gales N (2006a) Interpreting short-term behavioural responses to disturbance within a longitudinal perspective. Anim Behav 72: 1149-1158

Bejder L, Samuels A, Whitehead H, Gales N and others (2006b) Decline in relative abundance of bottlenose dolphins exposed to long-term disturbance. Conserv Biol 20:1791-1798

Berggren P, Amir OA, Guissamulo A, Jiddawi NS and others (2007) Sustainable dolphin tourism in East Africa. MASMA Technical Report. WIOMSA Book Series No. 7. Western Indian Ocean Marine Science Association (WIOMSA), Zanzibar

Bishop CM (1999) The maximum oxygen consumption and aerobic scope of birds and mammals: getting to the heart of the matter. Proc Biol Sci 266:2275-2281

Caswell H (2001) Matrix population models. Sinauer Associates, Boston, MA

Constantine R, Baker CS (1997) Monitoring the commercial swim-with-dolphin operations in the Bay of Islands, New Zealand. Department of Conservation, Wellington

Constantine R, Brunton DH, Baker CS (2003) Effects of tourism on behavioural ecology of bottlenose dolphins of northeastern New Zealand. Department of Conservation, Wellington

> Constantine R, Brunton DH, Dennis T (2004) Dolphin-watching tour boats change bottlenose dolphin (Tursiops truncatus) behaviour. Biol Conserv 117:299-307

- Corkeron PJ (2004) Whale watching, iconography, and marine conservation. Conserv Biol 18:847-849

$>$ Duffus DA, Dearden P (1990) Non-consumptive wildlife-oriented recreation: a conceptual framework. Biol Conserv 53:213-231

Duffus DA, Dearden P (1993) Recreational use, valuation, and management of killer whales (Orcinus orca) on Canada's Pacific Coast. Environ Conserv 20:149-156

Englund A (2001) The impact of tourism on Indo-Pacific bottlenose dolphins (Tursiops aduncus) in Menai Bay, Zanzibar. Honours thesis, Stockholm University

Fleiss JL (1981) Statistical methods for rates and proportions. Wiley, New York 
Forest AM (1999) The Hawaiian spinner dolphin (Stenella longirostris): Effects of tourism. Wild dolphin swim program workshop. 13th Biennial Conference on the Biology of Marine Mammals. Maui, HI

Frohoff TG (2001) Impacts of human interaction on odontocetes: A review and assessment. Abstracts. 14th Biennial Conference on the Biology of Marine Mammals. Vancouver, BC

Guttorp P (1995) Stochastic modeling of scientific data. Chapman \& Hall, London

Hoyt E (1993) Saving whales by watching them. New Sci 138: $45-46$

Hoyt E (2001) Whale watching 2001: worldwide tourism numbers, expenditures and expanding socioeconomic benefits. International Fund for Animal Welfare, Yarmouth Port, MA

Janik VM, Thompson PM (1996) Changes in surfacing patterns of bottlenose dolphins in response to boat traffic. Mar Mamm Sci 12:597-602

Jedensjö M (2005) The effect of violated guidelines on the behaviour of Indo-Pacific bottlenose dolphins off the south coast of Zanzibar. Honours thesis, Stockholm University

> Jensen FH, Bejder L, Wahlberg M, Aguilar Soto N, Johnson M, Madsen PT (2009) Vessel noise effects on delphinid communication. Mar Ecol Prog Ser 395:161-175

Lusseau D (2003a) Effects of tour boats on the behavior of bottlenose dolphins: using Markov chains to model anthropogenic impacts. Conserv Biol 17:1785-1793

Lusseau D (2003b) Male and female bottlenose dolphins Tursiops spp. have different strategies to avoid interactions with tour boats in Doubtful Sound, New Zealand. Mar Ecol Prog Ser 257:267-274

Lusseau D (2004) The hidden cost of tourism: detecting longterm effects of tourism using behavioural information. Ecol Soc 9:2

Lusseau D (2005) The residency pattern of bottlenose dolphins (Tursiops spp.) in Milford Sound, New Zealand, is

Editorial responsibility: Giovanni Bearzi, Milan, Italy related to boat traffic. Mar Ecol Prog Ser 295:265-272

Lusseau D, Slooten E, Currey RJ (2006) Unsustainable dolphin watching activities in Fiordland, New Zealand. Tourism Mar Environ 3:173-178

- Mann J, Smuts B (1999) Behavioral development in wild bottlenose dolphin newborns (Tursiops sp.). Behaviour 136:529-566

Nowacek SM, Wells RS, Solow AR (2001) Short-term effects of boat traffic on bottlenose dolphins, Tursiops truncatus, in Sarasota Bay, Florida. Mar Mamm Sci 17:673-688

Orams MB (1997) The effectiveness of environmental education: Can we turn tourists into 'Greenies'? Progr Tourism Hospit Res 3:295-306

> Smolker RA, Richards AF, Connor RC, Pepper JW (1992) Sex differences in patterns of association among Indian Ocean bottlenose dolphins. Behaviour 123:38-69

Spradlin TR, Barre LM, Lewandowski JK, Nitta ET (2001) Too close for comfort: concern about the growing trend in public interactions with wild marine mammals. Mar Mamm Soc Newsl 9:3-5

Stensland E, Berggren P (2007) Behavioural changes in female Indo-Pacific bottlenose dolphins in response to boat-based tourism. Mar Ecol Prog Ser 332:225-234

Stensland E, Carlén I, Särnblad A, Bignert A, Berggren P (2006) Population size, distribution and behavior of IndoPacific bottlenose dolphins (Tursiops aduncus) and humpback dolphins (Sousa chinensis) off the south coast of Zanzibar. Mar Mamm Sci 22:667-682

- Van Parijs SM, Corkeron P (2001) Boat traffic affects the acoustic behaviour of Pacific humpback dolphins, Sousa chinensis. J Mar Biol Assoc UK 81:533-538

Wells RS (1993) The marine mammals of Sarasota Bay. In: Sarasota Bay: 1992 Framework for Action: 9.1-9.23. Sarasota Bay National Estuary Program, Sarasota, FL

Williams R, Lusseau D, Hammond PS (2006) Estimating relative energetic costs of human disturbance to killer whales (Orcinus orca). Biol Conserv 133:301-311

Submitted: April 11, 2009; Accepted: December 21, 2009 Proofs received from author(s): March 5, 2010 